\title{
Empirical Studies of Financial Innovation: Lots of Talk, Little Action?
}

\author{
W. Scott Frame \\ Research Department \\ Federal Reserve Bank of Atlanta \\ 104 Marietta Street NW \\ Atlanta GA 30303 \\ Tel: 404-498-8783 \\ Fax: 404-498-8810 \\ e-mail: scott.frame@atl.frb.org \\ Lawrence J. White \\ Stern School of Business \\ New York University \\ 44 West $4^{\text {th }}$ Street \\ New York, NY 10012-1126 \\ Tel: 212-998-0880 \\ Fax: 212-995-4218 \\ e-mail: 1white@stern.nyu.edu
}

\begin{abstract}
This paper reviews the extant empirical studies of financial innovation. Adopting broad criteria, we found just two-dozen studies (24), over half of which (14) had been conducted since 2000. Since some financial innovations are examined by more than one study, only 14 distinct phenomena have been covered. Especially striking is the fact that only two studies are directed at the hypotheses advanced in many broad descriptive articles concerning the environmental conditions (e.g., regulation, taxes, unstable macroeconomic conditions, and ripe technologies) spurring financial innovation. We offer some tentative conjectures as to why empirical studies of financial innovation are comparatively rare. Among our suggested culprits is an absence of accessible data. We urge financial regulators to undertake more surveys of financial innovation and to make the survey data more available to researchers.
\end{abstract}

JEL Classification Numbers: G00, O31

Keywords: Financial innovation; banking; securities; patents

The views expressed in this paper do not necessarily reflect those of the Federal Reserve Bank of Atlanta, the Federal Reserve System, or their staffs. The authors thank Allen Berger, Robert DeYoung, Richard Nelson, Peter Tufano, and seminar participants at the Federal Reserve Bank of Philadelphia's conference on "Innovation in Financial Services and Payments" and the 2002 Western Economic Association International meetings. 


\section{Empirical Studies of Financial Innovation: Lots of Talk, Little Action?}

"... the word revolution is entirely appropriate for describing the changes in financial institutions and instruments that have occurred in the past twenty years." Miller (1986, p. 437)

"Everybody talks about the weather, but nobody does anything about it." Mark Twain (attributed)

"Everybody talks about financial innovation, but (almost) nobody empirically tests hypotheses about it." Frame and White

\section{Introduction}

The rising importance of the financial sector in modern economies, as well as the rapid rate of innovation in that sector, has generated a research interest in financial innovation. Indeed, a broad descriptive literature that discusses recent financial innovations and that advances various hypotheses about them has arisen (Van Horne 1985; Miller 1986, 1992; Mayer 1986; Cooper 1986; Faulhaber and Baumol 1988; Campbell 1988, ch. 16; Siegel 1990; Finnerty 1992; Merton 1992; Kopcke 1995; Tufano 1995; Lea 1996; Finnerty and Emery, 2002).

A striking feature of this literature, however, is the relative dearth of empirical studies that test hypotheses or otherwise provide a quantitative analysis of financial innovation. This is surprising given the relative abundance of similar papers for other sectors of the economy, especially manufacturing and agriculture.

One stark indicator of this dearth is found in two earlier survey articles of innovation generally (Cohen and Levin 1989; Cohen 1995). Cohen and Levin (1989) included 251 articles and books (bqth theoretical and empirical) in their bibliography, none of which pertain to financial services; ${ }^{1}$ Cohen (1995) updates the earlier survey and includes 357 books and articles, none of which pertain to financial services. In our current efforts to scour the financial literature landscape, using fairly broad criteria, we could find only two-dozen articles that provide empirical tests of

\footnotetext{
${ }^{1}$ The closest that Cohen and Levin come to any mention of financial services was a discussion of three articles that used stock market event studies to measure the effects of specific (non-financial) innovations.
} 
hypotheses concerning financial innovation; and, as we show below, the actual phenomena studied are appreciably fewer, since a number of these papers have focused on the same handful of innovations. Even more striking, only two studies are directed at the hypotheses that are advanced in that broad descriptive literature.

This paper will provide a słvey of the literature on financial innovation, with a special emphasis on the empirical articles. ${ }^{2}$ Along the way, we will provide an analytic structure for understanding and organizing the types of financial innovations and the hypotheses that have been advanced to explain the patterns of financial innovation. We will also offer some conjectures as to why empirical testing has been so scarce in this area.

This paper will proceed as follows. Section II provides motivation for this review: what is financial innovation? and why is financial innovation important? Section III describes the various factors that tend to influence the flow of innovations generally and the flow of financial innovations specifically. Section IV outlines several research questions that would be appropriate for empirical research on financial innovation. Section $\mathrm{V}$ surveys the existing empirical studies of financial innovation. Section VI offers some possible reasons for the paucity of empirical studies. Concluding remarks are provided in Section VII.

\section{Some Background}

Although financial innovation is all around us - the plastic in our wallets, the new financial instruments listed in the daily financial pages, the now-ubiquitous automatic teller machines (ATMs) that likely dispensed most of the cash that we carry in our purses and pockets -- a background discussion of financial innovation will be worthwhile.

\footnotetext{
${ }^{2}$ Although we have not found a comparable survey of the theoretical literature related to financial innovation, Duffie and Rahi (1995) introduce a special issue of the Journal of Economic Theory that focuses on financial innovation and security design.
} 


\section{A. What is financial innovation?}

"The primary function of the financial system is to facilitate the allocation and deployment of economic resources, both spatially and across time, in an uncertain environment." (Merton 1992, p. 12) This function, in turn, encompasses a payments system with a medium of exchange; the transfer of resources from savers to investor-users of the resources (and the eventual repayment to the savers); the gathering of savings for the purposes of pure time transformation (i.e., deferral/smoothing of consumption); and the reduction of risk through insurance and diversification.

The operation of a financial system involves real resource costs, such as labor, materials, and capital employed by financial intermediaries (e.g., banks, insurance companies, etc.) and by financial facilitators (e.g., stock brokers, market makers, financial advisors, etc.). Further, since multiple time periods are an inherent characteristic of finance, there are also uncertainties about future states of the world that generate risks. For risk-averse individuals, these risks represent costs. The possibility of new financial products/services/instruments that can better satisfy financial system participants' demands is always present. Viewed in this context, a financial innovation represents something new that reduces costs, reduces risks, or provides an improved product/service/instrument that better satisfies participants' demands.

Financial innovations can be grouped as new products (e.g., adjustable rate mortgages; exchange-traded index funds); new services (e.g., on-line securities trading; Internet banking); new "production" processes (e.g., electronic record-keeping for securities; credit scoring); or new

organizational forms (e.g., a new type of electronic exchange for trading securities; Internet-only banks). Of course, if a new intermediate product or service is created and used by financial services firms, then it may become part of a new financial production process.

There are close analogies with familiar forms of innovation in non-financial contexts. 
There we see new products (e.g., DVD players; self-stick postage stamps); new services (e.g., Internet-based retail shopping); new production processes (e.g., improved processes for manufacturing comptter chips) and new organizational forms (e.g., the "M-form" decentralized corporate structure). ${ }^{3}$ And innovations in producer goods are often essential for innovations in production processes.

Much of the research attention to innovation focuses on the new idea. But at least as important is the adoption and spread of an innovation -- its diffusion -- across an industry. Indeed, faster diffusion means a higher societal return on the underlying investments in the innovation.

\section{B. Why is financial innovation important?}

Innovation is clearly an important phenomenon in any sector of a modern economy. Although standard microeconomic theory (rightly) focuses much of its attention on the issues of static resource allocation and economic efficiency, there is neverthefess general appreciatipn that performance over time is driven by a variety of dynamic factors, ${ }^{4}$ including innovation. ${ }^{5}$ The centrality of finance in an economy and its importance for economic growth (e.g., Levine, 1997) naturally raises the importance of financial innovation. Since finance is an input for virtually all production activity and much consumption activity, improvements in the financial sector will have positive direct ramifications throughout the economy. Further, since better finance can encourage more saving and investment and can also encourage better (more productive) investment decisions,

\footnotetext{
${ }^{3}$ The M-form structure was originally discussed by Drucker (1946), Sloan (1964), Chandler (1962), and Williamson (1975).

4 "Making the best use of resources at any moment in time is important. But in the long run, it is dynamic performance that counts" (Scherer and Ross, 1990, p. 613).

${ }^{5}$ From Solow (1957) onward, there has been a widespread realization that expansions of the capital stock of an economy are responsible for only a modest fraction of economic growth. The remainder, or residual, is due to a number of factors, of which research and development and the resultant innovations are a major component (Scherer and Ross 1990).
} 
these indirect positive effects from financial innovation are yet greater still.

\section{What Motivates Innovation in General and Financial Innovation in Particular?}

Profit-seeking enterprises and individuals are constantly seeking new and improved products, processes, and organizational structures that will reduce their costs of production, better satisfy customer demands, and yield greater profits. Sometimes this search occurs through formal research and development programs; sometimes it occurs throwgh more informal "tinkering" or trial and error efforts. When successful, the result is an innovation. ${ }^{6}$

If the search-and-success were a relatively constant phenomenon, innovations would tend to appear in a roughly continuous stream. However, since the observed streams of innovations do not appear to be uniform across all enterprises, across all industries, or across all time periods, the general innovation literature (see Cohen and Levin 1989; Cohen 1995) has sought to uncover the environmental conditions that may encourage greater (or lesser) search efforts and a larger (or smaller) stream of innovations. That literature has focused on hypotheses concerning roughly five structural conditions: (1) the market power of enterprises; (2) the size of enterprises; (3) technological opportunity; (4) appropriability; and (5) product market demand conditions. We will first briefly sketch these general conditions and then will focus on financial innovation and the environmental factors that the descriptive literature (cited above) suggests may encourage financial innovation; we will also relate these latter factors back to the general conditions.

\section{A. General structural conditions.}

1. Market power. This hypothesis originates with Schumpeter (1950), who argued that market power is necessary to permit firms to generate sufficient returns from innovation. This is

\footnotetext{
${ }^{6}$ We will not here try to delve deeper into the "microstructure" of specifically how and why a "flash of inspiration" arises, generating an idea that eventually becomes an innovation.
} 
because of: (1) the inherent public good/free rider problems associated with new ideas, and (2) the difficulties of obtaining the finance for the sizable and uncertain investment in research and development (R\&D) that is often required for successful innovation.

2. Enterprise size. This hypothesis also is identified with Schumpeter (1950). A larger size of an enterprise implies that the sale of the product embodying the innovation is likely to be large, yielding a greater return on the investment in the innovation. Also, greater size is necessary to allow the firm to accommodate the economies of scale inherent in R\&D facilities, which are necessary to yield innovations. Finally, greater size is more likely to accommodate a wider range of activities and products, which may allow the firm to capture more of the unexpected spin-offs of the uncertain R\&D process. ${ }^{7}$

3. Technological opportunity. Some industry technologies seem inherently more susceptible to innovation. For the past few decades, for example, computer chips, hardware, and software have experienced rapid technological progress; in earlier decades, the chemical industry seemed to have this susceptibility.

4. Appropriability. As mentioned above, information has the properties of a public good. In the absence of some protection or frictions, a productive new idea will be rapidly copied by rivals (who, in a competitive marketplace, will price their output at marginal cost), thereby depriving the originator a return on his original investment in the innovation. The property rights regimes embodied in patents, copyrights, and trademarks provide some protections for innovators. Trade secrets and proprietary know-how provide additional protections, even where formal intellectual property protections are not available.

5. Product market demand conditions. Market size and growth are the main features

\footnotetext{
${ }^{7}$ Implicit in this discussion is the notion that innovations - expected and unexpected - are difficult to license or sell to other enterprises (because of asymmetric information problems), so that a firm must rely on its own capabilities. This is, of course, related to the appropriability issues discussed below.
} 
capturing product market demand conditions. Specifically, a larger market will provide a greater return to a successful innovative effort, while a growing market is likely to provide the rents (profits) that can both entice and finance innovation. Other market characteristics might also be influential, such as the variability of demand, general macroeconomic conditions, tax regimes, regulatory regimes, etc.

It should be emphasized that these conditions are hypotheses, to which counter-hypotheses have sometimes been offered. For example, in contrast to the Schumpeterian hypotheses that suggest that monopoly and giant size are conducive to rapid innovation, Scherer (1984) suggests that smaller firms, with (at most) only modest levels of market power, may be more likely to be rapid innowators, because of the competitive pressures that are absent in the "quiet life" world of monopoly. . $^{2}$

\section{B. The conditions that influence "equilibrium" rates of financial innovation.}

The descriptive literature that we cited above has suggested a number of environmental factors that have encouraged financial innovation. The list provided by Campbell (1988, ch. 16) is the most inclusive, and we will draw heavily on it. But, as good as Campbell's list is, it is seriously incomplete, because it focuses only on the levels of environmental factors and neglects changes in environmental factors, as we will explain below.

1. Underlying technologies. The basic underlying "physical" technologies of finance are those of telecommunications and data processing, which permit the gathering of information, its transmission, and its analysis. Increasingly, these technologies allow financial market participants to measure and manage their risk exposures more efficiently and effectively. For example, with respect to lending, asymmetric information problems imply that lenders have difficulties

\footnotetext{
${ }^{8}$ And in response, Schumpeter (1950) likely would have argued that the possibilities of entry by one giant firm into another's field was always enough of a possibility that the "quiet life" was not a likely prospect.
} 
determining who is a creditworthy borrower (adverse selection) and also have difficulties monitoring borrowers after a loan has been made (moral hazard). Accordingly, better (more advanced, faster, lower cost) physical technologies have permitted more innovations (e.g., credit and behavioral scoring) that allow lenders better to overcome those asymmetric information problems. Similarly, in terms of market risk, the use of value-at-risk and portfolio stress testing provide useful risk measures that can be used internally to set risk tolerance levels or allocate capital and externally to provide investors with a sense of overall exposure. Better physical technologies may also permit organizational innovations (e.g., electronic securities exchanges) that would not be possible with less advanced technologies.

There is another technological dimension that is important for finance: intellectual technologies, such as the Black-Scholes option pricing model or the capital-asset-pricing model (CAPM). Advances in these technologies will, again, permit a wider range of innovations (e.g., computer programs that will readily compute option values).

This category of environmental conditions for financial innovation has a direct parallel to the "technological opportunity" category of the general list above.

2. Macroeconomic conditions. Unstable macroeconomic conditions -- e.g., fluctuating prices, interest rates, exchange rates -- create uncertainties and risks and thus are likely to spur more innovation (to alleviate those risks) than would be true in a stable macroeconomic environment. Greater instability is likely to be associated with a faster pace of innovation.

This environmental condition seems best categorized as a parallel of "product market demand conditions" in the general list.

3. Regulation (legal environment). ${ }^{9}$ Regulation is a two-edged sword. On the one hand, some forms of regulation must inhibit innovation. For example, if regulation prevents commercial

\footnotetext{
${ }^{9}$ A more extensive discussion of the interaction between regulation and financial innovation can be found in White (2000).
} 
banks from owning insurance companies (and vice-versa), then whatever innovations might arise from joint ownership and operation will not occur. But, on the other hand, it is also clear that innovation can arise from efforts to circumvent regulation. To continue with the bank/insurance example, if cross-ownership is prevented, then banks will have the incentive to create insurancelike products and services (but, of course, will avoid labeling them as insurance), while insurance companies will have an incentive to create bank-like products. Accordingly, it is impossible $a$ priori to assign a positive or negative sign to the connection between the stringency of regulation (however measured) and the pace of financial innovation.

Also, the innovation that arises as a consequence of regulation may be a socially positive or negative phenomenon. This depends on whether one sees the regulation itself as socially worthwhile (so that innovative evasion is a waste of resources or may even have socially deleterious consequences) or as a social waste (in which case the innovative evasion is a second-best improvement).

Again, this environmental condition seems best categorized as a parallel of "product market demand conditions" in the general list.

4. Taxes. To the extent that a tax system levies differential taxes on different streams of income or on different categories of assets, the higher taxed parties will seek ways of reducing their taxes. Financial innovation will follow. Higher levels of taxation will likely yield a larger flow of innovation. Again, whether one sees this innovation as a socially positive or negative phenomenon will depend on the social interpretation that one puts on the differential taxation scheme.

Again, this environmental condition seems best categorized as a parallel to "product market demand conditions" in the general list.

5. Other influences? It is noteworthy that Campbell's list does not include appropriability (and the intellectual property considerations that are associated with appropriability) or the Schumpeterian hypotheses of firm size and market power. Traditionally, the intellectual property 
protection system (i.e., patent, copyright, trademark) has not been considered important for financial innovation; patents for financial innovations were a rare phenomenon before 1980 and only became noticeable and significant in the late-1990s (Lerner 2002). Since Tufano (1989) shows that imitation of some innovations is rapid, a regime of intellectual property protection could encourage greater innovation. ${ }^{10}$ As for the Schumpeterian hypotheses, the absence of formal R\&D facilities in financial services firms has probably been a significant factor in the relative neglect of the size and market-power considerations with respect to financial innovation.

Also, neither the general innovation literature nor the financial innovation literature has satisfactorily addressed how the presence of network externality effects (Rohlfs 1974) influences the type and pace of innovation. ${ }^{11}$ With networks, the benefits to membership increase as more members join the network. Also, economies of scale and compatibility among members are usually important features of networks. The implications for innovation are cloudy, but potentially important. Incremental innovations within the compatibility confines of a network are clearly possible. But the scale-related problems of creating new networks may discourage such "large" innovations.

6. Interactive effects. The categories discussed above are not mutually exclusive. There may well be interactions among them. For example, regulations that are non-binding under one set of environmental conditions may be binding under another and may inspire circumventing innovations in the latter state, provided that the technological capabilities are present. For example, it is clear that the greater macroeconomic fluctuations of the late 1960s and the 1970s caused a tighter binding of the Federal Reserve's Regulation Q (which limited the payment of interest on

\footnotetext{
${ }^{10}$ It is also possible, however, that excessively broad protection for ideas could discourage follow-on innovation, because of the transaction costs of negotiations between the original innovator and the follow-on innovators.

${ }^{11}$ The exception in the financial innovation literature, which we note below, is Saloner and Shepard (1995).
} 
bank deposits). This, in turn, inspired innovations such as money market mutual funds, "sweep accounts" for bank deposits, and Merrill Lynch's "cash management account"; but these innovations would not have been possible without the improved computer and telecommunications capabilities of the 1970 s.

\section{Changes in environmental conditions.}

The environmental factors described above represent the influences on the "equilibrium" flow of financial innovation. What is left out of that discussion is the consequences of a change in an environmental condition. When changes occur, we expect an initial wave or flurry of financial innovations that represent an initial response; the flow of innovations will then, over time, settle to a new equilibrium flow that is appropriate to the new environmental conditions. ${ }^{12}$ Thus a significant change in any of the major environmental categories would likely induce (with some lag) its own initial wave of innovations that would eventually settle to a lower equilibrium rate.

For example, the end of fixed exchange rates and the greater uncertainty surrounding fluctuating exchange rates in the early 1970s would naturally have led to an initial flurry of financial innovations -- foreign exchange, futures, forwards, and options -- to respond to the regime change. Such contracts might have been feasible before the change but simply were not in demand.

\footnotetext{
${ }^{12}$ We can offer a few analogies. First, for durable goods, it is generally believed (Pindyk and Rubinfeld 2001, p. 36) that the elasticity of demand is greater in the short run than in the long run (unlike the presumption that applies to non-durables). This is because (say) a price decrease causes an immediate flurry of buying activity, which is then followed by a reversion to a longer-run stock-replacement equilibrium. Similarly, in understanding the perceived pattern of law suits, law-and-economics theory (e.g., Priest and Klein 1984; Salop and White 1986) has postulated that the flow of suits is larger when litigants have mutually inconsistent expectations as to the likely outcomes (and each side is excessively optimistic as to its own prospects and so insists on proceeding to a trial rather than reaching a settlement that would economize on further legal costs). A change in a law or in a Supreme Court interpretation will generate a period of greater uncertainty as to how judges and juries will decide cases, leading to a wave of new law suits (that do not settle) until subsequent legal decision patterns are revealed and the litigants can form clearer expectations as to their prospects.
} 
After this initial wave (which could be of indeterminate length, because of lags), financial innovation in this area would settle to a new equilibrium flow (which would likely be greater than the old equilibrium flow because of the changed environment). And if the system of exchange rates were perceived to shift to a new "regime" of even greater variability, then we would expect to see another flurry of innovation.

Accordingly, it appears that the wave of innovations of the 1970s and 1980s that inspired the descriptive literature that we cited above ${ }^{13}$ was in part a response to changes in important environmental factors at the time, such as the rise in levels and variance of interest rates; the end of the Bretton Woods regime of fixed exchange rates; rapid technological changes in telecommunications and data processing; and major intellectual breakthroughs, such as the BlackScholes model. This perception of a wave due to changes in the environment would be consistent with Miller's (1986, p. 471) prediction that "the prospect for the future is for a slowing down of the rate of financial innovation ... a slowing down of innovation, not an end to further progress."

Further, in this context of environmental changes, even if a regulation or a tax rate changes in a direction that creates an environment that would induce a reduced equilibrium flow of evasionmotivated innovations, there might nevertheless be an initial wave of greater innovation as the participants in the financial markets adjust to the new environment.

Finally, these dynamic considerations are probably best categorized as a parallel to the "product market demand conditions" of the general list.

\section{Potential Empirical Research Questions Concerning Financial Innovation}

\footnotetext{
13 "A partial list of major novelties would include, in no particular order: negotiable CDs, Eurodollar accounts, Eurobonds, sushi bonds, floating-rate bonds, putable bonds, zero coupon bonds, stripped bonds, options, financial futures, options on futures, options on indexes, money market funds, cash management accounts, income warrants, collateralized mortgages, home equity loans, currency swaps, floor-ceiling swaps, exchangeable bonds, and on and on. The mind boggles" (Miller 1986, p. 437).
} 
What are the interesting research questions concerning financial innovation that could be explored empirically? We pose this question primarily as a way of establishing a framework for organizing the actual empirical studies that we review in the next section. However, it is a worthwhile question in its own right.

1. The environmental conditions that encourage innovation. As we discussed in the previous section, these are the research questions that have occupied much of the empirical literature on innovation generally. For financial innovation, the environmental factors that Campbell (1988) suggests, as well as the changes-in-environment considerations that we have added, would be a good starting place. Also, the intellectual property concerns of the general literature, the Schumpeterian hypotheses, af well as the consequences of network effects, would be interesting topics for empirical research. ${ }^{14}$ In addition, some additional characteristics of firms say, organizational form and the characteristics of senior management - may be important.

2. The customers for and users of innovations. This topic is somewhat related to the first, but is distinguishable. First, the actual innovators may be outside the financial services sector and are suppliers to it. Why does the innovation originate outside the financial sector rather than within it? Who are the adopters within the financial sector? What are their characteristics? Second, for innovations of new financial products aimed at retail users, who are the latter and what are their characteristics?

3. Diffusion. The rapidity with which an innovation is adopted across an industry is an interesting question that is separate from those that focus on where and how innovations first arise.

\footnotetext{
${ }^{14}$ For example, casual empiricism leads us to notice that relatively large financial services providers have been important innovators. Merrill Lynch was the developer of the "cash management account"; Salomon Brothers was the leader in developing stripped Treasury securities; the larger commercial banks led in developing and offering "sweep" accounts, ATMs, and Internet transactions for customers. But it would be useful to have a more formal "census" of innovations and their originators and the characteristics of those innovators. Perhaps smaller institutions have been significant innovators in ways that have escaped our attention.
} 
Who are the early adopters? What are their characteristics? What are the conditions that encourage rapid spread? Is geography important?

4. Consequences: profitability and social welfare. What are the consequences of financial innovation in terms of the pay-offs to the innovators and the impact on society as a whole? At first blush this latter question may seem to be an uninteresting one to ask. After all, innovation generally does seem to have positive social effects in raising real incomes. Nevertheless, there are three strands of theoretical literature that point to potentially negative social welfare outcomes from innovation and related activities. First, a steady sequence of slightly improved innovations that progressively supplant each other - each of which appears profitable and worthwhile from a myopic perspective that ignores what follows -- could lead to a net negative social welfare outcome, where the sum of the successive sunk investment costs exceeds the marginal cost reductions that they accomplish (Tirole 1988, p. 399). Second, the duplication of effort in patent races can have a net negative social welfare outcome (Tirole, 1988, p. 399). Third, information generation and related innovatipns that are focused purely on rent-seeking distributional struggles have a negative social value. $^{15}$

Indeed, some of the general descriptive literature on financial innovation has a somewhat defensive tone, in that the authors feel required to argue that the financial innovations are not socially harmful. ${ }^{16}$ The authors seem to be addressing fears that the innovations will simply lead to more transactions or churning in the financial markets, without net gains; that the innovations will create greater instability of securities markets; that the innovations will allow the taking of greater

\footnotetext{
${ }^{15}$ For example, suppose that person A owns a house on a flood plain and person B is considering buying it. Both may invest considerable resources in weather forecasting - maybe even invent some new forecasting devices or algorithms -- so as to determine the probabilities of a heavy rainfall and ruinous flood, which then helps determine the appropriate price for the house. But, if nothing can be done to prevent the flood - if this is solely a distributional question - then the expenditures have a negative social value.

${ }^{16}$ Consider the titles chosen by Van Horne (1985) ("Of Financial Innovations and Excesses") and by Mayer (1986) ("Financial Innovation: Curse or Blessing?").
} 
risks; and/or that the innovations can be inappropriately used by unsophisticated parties to the latter's detriment.

In sum, there is a wide range of interesting empirical questions that can be addressed in research on financial innovation.

\section{Empirical Studies of Financial Innovation}

This section reviews the extant empirical literature on financial innovation. There were two broad criteria for inclusion in the review:

- Empirical: The article must have formally presented data and tested hypotheses, so that a standard error appeared somewhere in the article. Thus, a purely descriptive article would not qualify.

- Innovation: The article must have examined a financial product/process/organization during a period when it was considered relatively novel. For example, studies of the deployment of ATMs using data from the late 1970's would be appropriate, but a similar study using data only from the late 1990's would not.

As an organizing framework, we use the research categories delineated in the previous section. ${ }^{17}$ The Appendix provides a concise description of the studies in terms of the economic questions examined, data samples employed, and conclusions.

\section{A. The environmental conditions that encourage innovation.}

We could find only two studies that focus primarily on the environmental conditions that

\footnotetext{
${ }^{17}$ Because of space constraints, these very brief reviews do not do full justice to the depth, breadth, and complexity of the articles that we review.
} 
encourage financial innovation.

Ben-Horim and Silber (1977) test the proposition that regulatory constraints induce innovation. They construct a linear programming model to estimate the opportunity costs (shadow prices) of deposits, debentures, and capital (net worth) for large banks from 1952-1972. They find that the rising shadow prices of these items, as they approached regulatory constraints (such as Regulation Q), were associated with some of the major innovations of the 1960s, such as the negotiable CD.

Lerner (2002) documented financial patenting activity in the late twentieth century (455 patents between 1971-2000). He notes that although the level of patenting activity has been modest, it increased markedly after a 1998 judicial decision (the State Street Bank case) that allowed for business method patents. Lerner also studies the patenting activity of investment banks and finds that it was positively related to the size of the investment banks and to the extent of their indirect academic ties. He also finds, however, that the direct involvement of academic institutions or of academics themselves in financial patenting was not related to finance-related research productivity of the institutions or the individuals.

\section{B. The customers for and users of innovations.}

We were able to find a somewhat larger number of studies that focused on the characteristics of customers for and users of financial innovations. These studies have focused on: 1) banks' adoption of Internet banking and small business credit scoring (SBCS), and 2) consumers' use of ATM cards, debit cards, and electronic bill payment services.

There have been two studies of commercial banks' adoption of Internet banking. ${ }^{18}$ Furst, Lang, and Nolle (2002) analyze survey data on Internet banking as of the third quarter of 1999.

\footnotetext{
${ }^{18}$ Internet banking refers to web-sites that are either exclusively informational in nature or offer the capability to conduct banking business on-line.
} 
Using logit models, they find that a bank's choice of adopting Internet banking is related to holding company affiliation, location in an urban area, higher fixed expenses, and higher non-interest income. Among banks that offer Internet-related services, a greater number of service offerings were positively related to bank size and the length of time-offering Internet banking. Sullivan (2000) compares banks in the $10^{\text {th }}$ Federal Reserve district ${ }^{19}$ that had transactional Internet websites as of the first quarter of 2000 to those that did not have such web-sites. He finds the former to be significantly larger and located in areas with a more educated population and a higher population fraction in the 18 to 64 age group. Banks offering transactional Internet web-sites are also found to have higher non-interest expenses and higher non-interest income.

In the course of their study of the effect of SBCS on large banks' portfolio of commercial loans under \$100,000 for 1997 (discussed below), Frame, Srinivasan, and Woosley (2001) find that the probability of adopting this process innovation was negatively related to the number of subsidiary banks, but positively related to the number of bank branches. This suggests a link between organizational structure and the adoption of certain technologies.

Mantel (2000) and Mantel and McHugh (2001) both use a consumer survey of 1,300 people to study usage of electronic bill payment and debit cards. In the former study, the usage of electronic bill payment services is found to be positively related to age, income, and gender (female). The latter study finds that debit card usage is related to age, income, and market size (population).

\section{Diffusion.}

We are aware of five studies of the diffusion of financial innovations, three of which focus on ATM deployment by banks. These studies generally use hazard models that estimate

\footnotetext{
${ }^{19}$ The $10^{\text {th }}$ Federal Reserve District encompasses Colorado, Kansas, Missouri, Nebraska, New Mexico, Oklahoma, and Wyoming.
} 
the adoption pattern of the innovation under study conditional on firm- and market-specific effects.

Hannan and McDowell (1984) find that -- consistent with the Schumpeterian hypotheses -larger banks and those operating in more concentrated local banking markets registered a higher conditional probability of ATM adoption. This study also found bank product mix, bank holding company affiliation, urban location, branch banking restrictions, and the area wage rate were all positively related to ATM adoption.

In a subsequent study, Hannan and McDowell (1987) find that the conditional probability of ATM adoption is positively related to a rival's adoption and that firms in less concentrated markets react more strongly to rival precedence than do their counterparts in concentrated markets. Consistent with their previous results, bank size and local market concentration were positively related to ATM adoption. Similar results were fornd for bank holding company affiliation, branch banking restrictions, and market deposit growth. ${ }^{20}$

Using the same data, Saloner and Shepherd (1995) find that the expected time to adoption of ATMs declines in both the number of users (deposits) and locations (branches), indicating the presence of network externalities. For limited branching states, market concentration is positively related to ATM adoption speed, while depositor growth is negatively related. For unrestricted states, the area bank wage rate is positively related to ATM adoption speed.

Molyneux and Shamroukh (1996) examine the diffusion of the underwriting of junk bonds and of note issuance facilities (NIFs) during the 1978-1988 and 1983-1986 periods, respectively. ${ }^{21}$ The authors find that exogenous factors, such as regulatory or demand changes, played a significant

\footnotetext{
${ }^{20}$ Interestingly, in this follow-up paper (and using the same data) the author's did not include the product mix and urban location variables that were significant in their initial paper.

${ }^{21}$ A note issuance facility is an arrangement by which a bank or group of banks agree to act as managers underwriting a borrower's issue on short-term paper as and when required and to back the facility with medium-term credit should the note not find a market (Molyneux and Shamroukh 1996, 513).
} 
role in the diffusion of junk bond underwriting. Conversely, the diffusion of NIFs underwriting appeared to be motivated by bandwagon effects. Molyneux and Shamroukh argue that banks (commercial and investment) are more likely to respond to competitive and institutional bandwagon pressures by adopting an innovation when it threatens an existing business, rather than when it represents new business opportunities. However, for both underwriting innovations, the authors find that adoption by one bank makes it more desirable for other banks to follow suit - and this effect increases in the number of adopters.

More recently, Akhavein, Frame, and White (2001) examine the diffusion of small business credit scoring (SBCS) by large banking organizations in the mid-1990s. Estimates from a hazard model indicate that larger banking organizations and those located in the New York Federal Reserve district adopted this technology sooner. A tobit model confirms these results and also finds that organizations with fewer separately chartered banks, but more branches, introduced innovation earlier, which is consistent with theories stressing the importance of bank organizational form on lending style.

\section{Consequences: Profitability and Social Welfare.}

Studies of the consequences of financial innovation represent the largest number of empirical studies.

Garbade and Silber (1978) examine the effects of a major input innovation for finance: the establishment of the telegraph in the nineteenth century. They find that the telegraph quickly narrowed inter-market price differentials for securities and for foreign exchange across U.S. markets in the 1840s and for bonds between New York and London in 1866. They also find that the establishment of the consolidated tape for New York Stock Exchange (NYSE) securities in 1975 did not cause price differentials to narrow between the NYSE and the Midwest Stock Exchange. For this latter case, the authors conclude that the pre-existing telecommunications links 
were likely sufficient, such that consolidated tape added little value.

Tufano (1989) examines a cross-section of new securities to examine whether financial product innovators enjoy first mover advantages. Specifically, he uses a sample of 58 innovations (representing 1,944 public offerings) to test whether investment banks that create new securities benefit by charging higher prices (underwriting spreads) than imitators or by capturing larger quantities. Tufano finds that, over the 1974-1986 period, investment banks that created new products did not charge higher prices in the period before imitative products appear and in the longrun charge lower prices than rivals. However, these innovators underwrote more public offerings of products that they innovated, than did imitating rivals. Overall, Tufano's results are not consistent with monopoly pricing of new securities issues by innovators, but rather with the presence of cost advantages that allow these institutions to capture market share.

Two papers examined the welfare effects of specific security innovations. First, Varma and Chambers (1990) study the wealtheffects associated with the issuance announcement of original issue deep discount (OID) bonds. ${ }^{22}$ They find that OID issues announced between March 1981 and June 1982 were associated with positive stekrice responses, while subsequent issues that were not tax-advantaged had no wealth effects. ${ }^{23}$ Neither the stated purpose of the debt nor the bond rating explained any cross-sectional variation in abnormal returns.

Second, Grinblatt and Longstaff (2000) find that investors use Treasury STRIPS to make markets more complete and to take advantage of tax and accounting asymmetries. ${ }^{24,25}$ The authors

${ }^{22}$ OID bonds are issued at prices below par and with coupons set below the market rate.

${ }^{23}$ This result contrasts with the negative effect often found for debt-financing announcements.

${ }^{24}$ STRIPS refer to the Separate Trading of Registered Interest and Principal of Securities. This program allows investors to strip Treasury notes and bonds and create separate discount bonds and reconstitute previously stripped notes and bonds.

${ }^{25}$ Theoretical models of security design (e.g., Allen and Gale 1988), suggest that successful derivatives allocate cash flows to the investors who value them the most, thereby allowing securities to be held in their most valuable form. 
estimate a joint model of stripping and reconstitution activity using data for 1990-1994 and find that such activities are positively correlated. They also find that stripping and reconstitution are not driven by valuation differences between Treasury STRIPS and comparable bonds, but rather to the presence of long-dated issues. Tax and accounting rationales, as proxied by bond coupon rates and prices, are also important to explaining these activities. In short, Grinblatt and Longstaff conclude that STRIPS are used for fundamental economic reasons, and not as attempts to exploit arbitrage profit opportunities.

Examination of the welfare effects of process financial innovations appears is limited to three recent studies focusing on large banking organizations' adoption of small business credit scoring (SBCS) in the mid-1990s. ${ }^{26}$ Frame, Srinivasan, and Woosley (2001) find that, for 1997, large banking organizations using SBCS had portfolio shares of small business loans under $\$ 100,000$ to total assets 8.4 percentage points higher than similar institutions that did not. Frame, Padhi, and Woosley (2001) use census-tract level information for the southeastern U.S. in 1997 and find that SBCS usage was related to increases in the volume of commercial credits under $\$ 100,000$ and that this effect is twice as large in low- and moderate-income census tracts than in middle and high-income areas. Finally, Berger, Frame, and Miller (2001) confirm the findings of increased credit availability for small businesses and also identify higher average prices and greater risk levels for these credits under $\$ 100,000$. The authors contend that this indicates increased lending to riskier "marginal" borrowers that, in the absence of SBCS, may not have had access to small business credit from banks at all. In looking at the 1995-1997 period, the authors also find that bank-specific and industry-wide learning curves for SBCS have important effects and that the welfare effects differed depending on the way a large bank utilized SBCS (i.e., as a more cost-

\footnotetext{
${ }^{26}$ It is worth noting that SBCS did not originate within the banking industry, but rather was pioneered by Fair, Isaac Company. Their original model, introduced in 1995, pooled small business loan performance data provided by Robert Morris Associates for 17 large U.S. banks. See Eisenbeis (1996) and Mester (1997) for discussions of the history of SBCS.
} 
effective way of underwriting loans or as a way of obtaining more accurate credit evaluations).

Four studies have empirically studied bank holding companies' (BHCs) formation of Section 20 subsidiaries to underwrite securities in the late 1980s and the 1990s. First, Bhargava and Fraser (1998), using event studies, find that BHCs experienced abnormal positive returns from the initial Federal Reserve decisions to permit banks to form and expand these subsidiaries, but negative abnormal returns from subsequent decisions to permit BHCs to expand their corporate underwriting. Second, Fields and Fraser (1999) find that the pay-performance sensitivity of the CEOs of BHCs that enter securities underwriting increases during their transition into underwriting but remains substantially less than the sensitivity found in investment banks. Third, Gande, Puri, and Saunders (1999) find that BHC entry into underwriting tended to decrease underwriting market concentration and, consistent with the consequent increased competition, decreased underwriter spreads and ex ante yields. Finally, Cornett, Ors, and Tehranian (2002) find that the pre-tax cash flow of BHCs that established Section 20 subsidiaries tended to increase, as compared to BHCs that did not establish subsidiaries and to investment banks. The change does appear to be due to their entry into the new line of business. The authors also find that the riskiness of the banks did not change subsequent to their entry.

The characteristics of Internet-only start-up (de novo) banks in the late 1990s have received attention from DeYoung (2001a, 2001b). He finds that, as compared with conventional de novo banks, the Internet de novos are less profitable, due to low business volumes (fewer deposits and lower non-interest income) and high labor expenditures. However, DeYoung's research also suggests that the financial performance of de novo Internet banks improves more quickly over time than does that of conventional de novos. He attributes these findings to: 1) technology-based learning effects, and 2) technology-specific scale effects. As a result, DeYoung's findings offer some hope that the Internet-only format may eventually be viable. 


\section{F. A summing up.}

We have surveyed the 24 empirical studies of financial innovation that we were able to uncover, using quite broad criteria. It is worth noting, however, that only 14 separate phemomena are covered, since some financial innovations are examined by more than one study. ${ }^{27}$ Some summary characteristics are in order:

- Only five studies precede the 1990s - and 14 have appeared since 2000 !

- Only two studies address the environmental conditions that encourage financial innovations. Thus, the hypotheses advanced by the broad descriptive literature on innovation remain largely untested. Five studies address the characteristics of the customers for and users of financial innovations. Six studies address the diffusion of financial innovations. The remaining studies examine consequences and (explicitly or implicitly) welfare effects.

- Only one study covers financial patenting; five cover innovations that pertain to securities or securities underwriting; the remaining 18 studies apply to banking.

- Two financial organizational innovations (the establishment of Section 20 subsidiaries by BHCs and Internet-only banks) are covered by six studies. Some studies cover financial product/service innovations (e.g., debit cards); some studies cover financial process innovations (e.g., small business credit scoring); and some studies covered innovations that could be described as a process or as a product/service depending on the perspective taken (e.g., the offering of Internet banking).

Taken together, these relatively few studies are suggestive (but not definitive) of some broader conclusions:

- Regulation does spur financial innovation, and this consequence should be considered before

\footnotetext{
${ }^{27}$ There are two studies of the characteristics of banks that offer Internet banking; two studies of start-up Internet-only banks; three studies of the diffusion of ATMs; four studies of the adoption of SBCS by large banks; and four studies of BHCs that established Section 20 subsidiaries.
} 
new policies are implemented.

- The adoption and diffusion of new technologies by banks is related to institution size.

- The use of new financial technologies by consumers is related to age, income, and population.

- The welfare effects of financial innovation appear to generally be positive. However, for organizational innovations this is less concrete.

It seems clear that considerably more empirical work is possible, especially for testing the hypotheses concerning the conditions that encourage innovation. Further, some of the results that have been established in one area (e.g., banking) could be expanded to others. Why this has not already happened will be the topic of the next section.

\section{Why Are There So Few?}

Despite the recognized importance of financial innovation and an extensive descriptive literature, there have been surprisingly few empirical studies. Why is this? We are not sure that we have all of the answers to this question, but we can offer some tentative (and somewhat interrelated) conjectures.

1. The research and development (R\&D) tradition. Outside of finance, much of the empirical testing has linked innovation with formal research and development efforts by companies. But this R\&D linkage has largely a manufacturing focus, involving research laboratories, R\&D budgets, and head-counts of scientists and engineers. The Natienal Science Foundation's (NSF) data collection and publication efforts have reinforced this focus. ${ }^{28}$

${ }^{28}$ From its initial year (1953) of data collection about "industrial" R\&D to the present, the NSF's focus has been on manufacturing. As of 1997 and 1998, the last years for which the NSF reported its annual industrial R\&D data on the basis of the "standard industrial classification" (SIC) system, manufacturing enterprises accounted for about three-quarters of all reported industrial R\&D and about two-thirds of all industrial scientists and engineers (NSF 2000). Also, as is true for almost all SIC-based industry-wide data, far more detail was available for the manufacturing sector than for other sectors. In 1999 and 2000, with the newer "North America industrial classification system" (NAICS), manufacturing enterprises accounted for three-fifths of NSF's reported industrial R\&D and three-fifths of scientists and engineers (NSF 2002). It is unclear as to whether the decrease in manufacturing's shares of $R \& D$ expenditures and personnel was a 
Financial services are not in this $R \& D$ tradition. Financial services firms rarely have R\&D budgets (though they de have IT budgets); they don't have laboratories; they rarely employ scientists and engineers. ${ }^{29}$ Therefore, empirical testing of hypotheses involving R\&D are unlikely to occur in financial services.

2. The patent count tradition. Another line of research (outside of finance) has involved patents and patent counts, and the testing of linkages between patent counts and the characteristics (including $\mathrm{R} \& \mathrm{D}$ ) of companies and of industries. However, patents for financial products and services are not common and finapjal services firms are unlikely to be boasting in advertisements about their patenting proclivities. ${ }^{30}$ Thus, empirical examinations of financial innovation using patent counts is unlikely to occur in financial services. Lerner (2002) is thus far the sole exception to this statement.

3. The data. The data that are commonly used for research about financial services -- e.g., the bank call reports, the Center for Research in Securities Prices (CRSP) data files, and Standard \& Poor's COMPUSTAT data files -- yield no directly useful information about financial innovation.

4. The industrial organization (IO) tradition. Much of the testing of hypotheses involving innovation has come from individuals trained in the economics specialty of industrial organization and has been focused (directly or indirectly) on testing the Schumpeterian hypotheses: that the bulk of an economy's innovation was likely to occur in relatively large firms that possess significant market power. This testing, as is true of much IO empirical work, has tended to focus on the

result of the change in the classification systems, changes in ownership of enterprises that would change the classification of their R\&D efforts, or just a secular change in manufacturing's shares.

${ }^{29}$ In 1997 and 1998 financial services firms accounted for less than 1\% of NSF's reported R\&D and 1-2\% of total scientists and engineers (NSF 2000). The data that are currently available for 2000 do not yet provide a sufficiently disaggregated classification of $\mathrm{R} \& \mathrm{D}$ expenditures to permit a corresponding estimate.

${ }^{30}$ The patent statistics of the U.S. Patent and Trademark Office for the 1990s indicate that over $90 \%$ of patents granted are for inventions in manufacturing. 
manufacturing sector, where the data (including not only the R\&D and patents data just discussed but also industry-level data on seller concentration) are more readily available.

Empirically-oriented finance economists (with a few exceptions) have usually not been trained in IO, have usually not been taught to think about the Schumpeterian hypotheses, and have had less suitable data available to them for testing those (or any other) hypotheses.

5. A summing up. The data and research environments have not been conducive to empirical work on financial innovation. Perhaps it is not surprising after all that relatively few research papers have empirically tested hypotheses concerning financial innovation.

The data question deserves a bit more consideration. For a number of empirical financial innovation studies, the crucial data have come from special surveys, often conducted by the Federal Reserve. We urge financial regulators to conduct and publish more such studies and surveys and to make the raw data (subject to the bounds of confidentiality requirements) generally available to researchers. We believe that the knowledge payoff in this area would be high.

\section{Conclusion}

In this paper we have surveyed and summarized the existing empirical literature on financial innovation. Along the way we have stressed the surprising fewness of research papers that empirically test hypotheses concerning financial innovation, although we have also offered some conjectures as to why that fewness might not be so surprising after all.

If, as Van Horne (1985, p. 621) has claimed, "One of the bedrocks of our financial system is financial innovation, the life blood of efficient and responsive capital markets," then more extensive empirical research on financial innovation would surely yield important and interesting insights about that bedrock. This research need not be confined to the Schumpeterian perspective. There is extensive room for improvements in our society's understanding of how innovations arise, how their characteristics compare with those of their predecessors, why they succeed or fail, how fast the 
successful innovations diffuse and why, who uses them and why, etc.

Financial innovation is all around us. Recall the extensive, "partial list of major novelties" offered by Miller (1986), which we noted above. The sixteen years since then have been at least as fruitful in terms of financial innovation. The business and financial press frequently report on new instruments, new processes, and new organizations. Many of the raw materials for empirical studies are already present, and "innovation-minded" researchers - perhaps aided by more regulatory surveys and greater access to them -- can surely supply the remainder.

We urge our fellow finance economists to expend some effort toiling in this relatively untilled field. We believe that the intellectual yields will be large. 


\section{References}

Akhavein, Jalal, W. Scott Frame, and Lawrence J. White, 2001. "The Diffusion of Financial Innovation: An Examination of the Adoption of Small Business Credit Scoring by Large Banking Organizations." Federal Reserve Bank of Atlanta Working Paper 2001-9.

Allen, Franklin and Douglas Gale, 1988. "Optimal Security Design," Review of Financial Studies, 3, 229-263.

Bhargava, Rahul and Donald R. Fraser, 1998. "On the Wealth and Risk Effects of Commercial Bank Expansion into Securities Underwriting: An Analysis of Section 20 Subsidiaries," Journal of Banking and Finance, 22 (May), 447-465.

Ben-Horim, Moshe and William L. Silber, 1977. "Financial Innovation: A Linear Programming Approach," Journal of Banking and Finance, 1 (November), 277-296.

Berger, Allen, W. Scott Frame, and Nathan Miller, 2002. "Credit Scoring and the Availability, Price and Risk of Small Business Credit." Federal Reserve Bank of Atlanta Working Paper 2002-6.

Campbell, Tim, 1988. Money and Capital Markets. Glenview, IL: Scott, Foresman.

Chandler, Alfred D., Jr., 1962. Strategy and Structure: Chapters in the History of the Industrial Enterprise. Cambridge, Mass.: MIT Press.

Cohen, Wesley, 1995. "Empirical Studies of Innovative Activity" in Handbook of the Economics of Innovation and Technological Change, edited by Paul Stoneman. Cambridge, Mass.: Blackwell. Ch. 6, 182-264.

Cohen, Wesley and Richard Levin, 1989. "Empirical Studies of Innovation and Market Structure" in Handbook of Industrial Organization, Vol. 2, edited by Richard Schmalensee and Robert Willig. Amsterdam: North-Holland. Ch. 18, 1059-1107.

Cooper, Ian, 1986. "Innovation: New Market Investments," Oxford Review of Economic Policy, 2 (December), 1-17.

Cornett, Marcia M., Everen Ors, and Hassan Tehranian, 2002. "Bank Performance around the Introduction of a Section 20 Subsidiary," Journal of Finance, 57 (February), 501-521.

DeYoung, Robert, 2001a. "The Financial Performance of Pure Play Internet Banks," Economic Perspectives, Federal Reserve Bank of Chicago, 25 (First Quarter), 60-75.

DeYoung, Robert, 2001b. "Learning-by-Doing, Scale Efficiencies, and Financial Performance at Internet-Only Banks," in The Financial Safety Net: Costs, Benefits, and Implications for 
Regulation, $37^{\text {th }}$ Annual Conference on Bank Structure and Competition, Federal Reserve Bank of Chicago, 315-327.

Drucker, Peter F., 1946. The Concept of the Corporation. New York: John Day.

Duffie, Darrell and Rohit Rahi, 1995. "Financial Market Innovation and Security Design: An Introduction," Journal of Economic Theory, 65 (February), 1-42.

Eisenbeis, Robert, 1996. "Recent Developments in the Application of Credit Scoring Techniques to the Evaluation of Commercial Loans." IMA Journal of Mathematics Applied in Business and Industry, 7, 271-290.

Faulhaber, Gerald and William Baumol, 1988. "Economists as Innovators: Practical Products of Theoretical Research," Journal of Economic Literature, 26 (June), 577-600.

Fields, L. Paige and Donald R. Fraser, 1999. "On the Compensation Implications of Commercial Bank Entry into Investment Banking," Journal of Banking and Finance, 23 (August), 1261-1276.

Finnerty, John, 1992. "An Overview of Corporate Securities Innovation," Journal of Applied Corporate Finance, 4 (Winter), 23-39.

Finnerty, John and Douglas Emery, 2002. "Corporate Securities Innovation: An Update," Journal of Applied Finance, 12 (Spring/Summer), 21-47.

Frame, W. Scott, Aruna Srinivasan, and Lynn Woolsey, 2001. "The Effect of Credit Scoring on Small Business Lending," Journal of Money, Credit, and Banking, 33 (August), 813-825.

Frame, W. Scott, Michael Padhi, and Lynn Woolsey, 2001. "The Effect of Credit Scoring on Small Business Lending in Low- and Moderate Income Areas." Federal Reserve Bank of Atlanta Working Paper 2001-6.

Furst, Karen, William Lang, and Daniel Nolle, 2000. "Internet Banking," Journal of Financial Services Research, 22 (August/October),

Gande, Amar, Manju Puri, and Anthony Saunders, 1999. "Bank Entry, Competition, and the Market for Corporate Securities Underwriting," Journal of Financial Economics, 54 (October), 165195.

Garbade, Kenneth and William Silber, 1978. "Technology, Communication, and the Performance of Financial Markets," Journal of Finance, 33 (June), 819-832.

Grinblatt, Mark and Francis A. Longstaff, 2000. "Financial Innovation and the Role of Derivative Securities: An Empirical Analysis of the Treasury STRIPS Program," Journal of Finance, 40 (June), 
1415-1436.

Hannan, Timothy and John McDowell, 1984. "The Determinants of Technology Adoption: The Case of the Banking Firm," Rand Journal of Economics, 15 (Autumn), 328-335.

Hannan, Timothy and John McDowell, 1987. "Rival Precedence and the Dynamics of Technology Adoption: An Empirical Analysis," Economica, 54 (May), 155-171.

Kopcke, Richard W., 1995. "Financial Innovation and Standards for the Capital of Life Insurance Companies," New England Economic Review, Federal Reserve Bank of Boston, January/February, 29-57.

Lea, Michael, 1996. "Innovation and the Cost of Credit: A Historical Perspective," Housing Policy Debate, 7, 147-174.

Lerner, Josh, 2002. "Where Does State Street Lead? A First Look at Finance Patents, 1971-2000," Journal of Finance, 57, 901-930.

Levine, Ross, 1997. "Financial Development and Economic Growth: Views and Agenda." Journal of Economic Literature, 35 (June), 688-726.

Mantel, Brian, 2000. "Why Do Consumers Pay Bills Electronically? An Empirical Analysis." Economic Perspectives, Federal Reserve Bank of Chicago, (Fourth Quarter), 32-47.

Mantel, Brian and Timothy McHugh, 2001 "Competition and Innovation in the Consumer ePayments Market? Considering Demand, Supply, and Public Policy Issues," Federal Reserve Bank of Chicago, Emerging Payments Occasional Working Paper Series (EPS-2001-4).

Mayer, Colin, 1986. "Financial Innovation: Curse or Blessing?" Oxford Review of Economic Policy, 2 (December), i-xix.

Merton, Robert C., 1992. "Financial Innovation and Economic Performance." Journal of Applied Corporate Finance, 4 (Winter), 12-22.

Mester, Loretta, 1997. "What's the Point of Credit Scoring?" Federal Reserve Bank of Philadelphia Business Review. (September/October), 3-16.

Miller, Merton H., 1992. "Financial Innovation: Achievements and Prospects," Journal of Applied Corporate Finance, 4 (Winter), 4-12.

Miller, Merton H., 1986. "Financial Innovation: The Last Twenty Years and the Next." Journal of Financial and Quantitative Analysis, , 21 (December), 459-471. 
Molyneux, Phil and Nidal Shamroukh, 1996. "Diffusion of Financial Innovations: The Case of Junk Bonds and Note Issuance Facilities," Journal of Money, Credit, and Banking, 28 (August), 502-522.

Pindyk, Robert S. and Daniel L. Rubinfeld, 2001. Microeconomics, 5th edn. Upper Saddle River, N.J.: Prentice Hall.

Priest, George L. and Benjamin Klein, 1984. "The Selection of Disputes for Litigation," Journal of Legal Studies, 13 (January), 1-55.

Rohlfs, Jeffrey, 1974. "A Theory of Interdependent Demand for a Communications Service," Bell Journal of Economics and Managerial Science, 5 (Spring), 16-37.

Saloner, Garth and Andrea Shepard, 1995. "Adoption of Technologies with Network Effects: An Empirical Examination of the Adoption of Automated Teller Machines," Rand Journal of Economics, 26 (Autumn), 479-501.

Salop, Steven C. and Lawrence J. White, 1986. "Economic Analysis of Private Antitrust Litigation," Georgetown Law Journal, 74 (April), 201-263.

Scherer, F.M., 1984. Innovation and Growth: Schumpeterian Perspectives. Cambridge, Mass.: MIT Press.

Scherer, F.M. and David Ross, 1990. Industrial Market Structure and Economic Performance. $3^{\text {rd }}$ ed. Boston: Houghton-Mifflin.

Schumpeter, Joseph A., 1950. Capitalism, Socialism, and Democracy, $3^{\text {rd }}$ edn. New York: Harper \& Brothers.

Siegel, Daniel, 1990. Innovation and Technology in the Markets: A Reordering of the World's Capital Market System. Chicago: Probus.

Sloan, Alfred P., Jr., 1964. My Years with General Motors. Garden City, N.Y.: Doubleday.

Solow, Robert M., 1957. "Technical Change and the Aggregate Production Function," Review of Economics and Statistics, 39 (August), 312-320.

Sullivan, Richard J., 2000. "How Has the Adoption of Internet Banking Affected Performance and Risk in Banks?" Financial Industry Perspectives, Federal Reserve Bank of Kansas City, 1-16.

Tirole, Jean, 1988. The Theory of Industrial Organization. Cambridge, Mass.: MIT Press.

Tufano, Peter, 1989. "Financial Innovation and First Mover Advantages," Journal of Financial Economics, 25, 213-240. 
Tufano, Peter, 1995. "Securities Innovations: A Historical and Functional Perspective," Journal of Applied Corporate Finance, 4 (Winter), 90-104.

Van Horne, James, 1985. "Of Financial Innovations and Excesses," Journal of Finance, 40 (July), 621-636.

Varma, Raj and Donald R. Chambers, 1990. "The Role of Financial Innovation in Raising Capital: Evidence from Deep Discount Debt Offers," Journal of Financial Economics, 26 (October), 289298.

White, Lawrence J., 2000. "Technological Change, Financial Innovation, and Financial Regulation in the U.S.: The Challenges for Public Policy," in Performance of Financial Institutions: Efficiency, Innovation, Regulation, edited by Patrick Harker and Stavros Zenios. Cambridge University Press. Ch. 12, 388-415.

Williamson Oliver E., 1975. Markets and Hierarchies -- Analysis and Antitrust Implications: A Study in the Economics of Internal Organization. New York: Free Press. 
Appendix: A Summary of Empirical Studies of Financial Innovation

Note: The studies in this appendix are listed in the order in which they appear in the discussion in the text.

\begin{tabular}{|c|c|c|c|}
\hline Broad Category; Study & Relevant Research Questions & Data & Principal Conclusions \\
\hline \multicolumn{4}{|l|}{ A. Environmental Conditions: } \\
\hline Ben-Horim and Silber (1977) & $\begin{array}{l}\text { Do regulatory restraints encourage } \\
\text { financial innovation? }\end{array}$ & $\begin{array}{l}\text { Federal Reserve data and other } \\
\text { sources }\end{array}$ & $\begin{array}{l}\text { Broadly speaking, regulatory } \\
\text { restraints do encourage innovation. }\end{array}$ \\
\hline Lerner (2002) & $\begin{array}{l}\text { How much financial patenting } \\
\text { occurred in the late } 20^{\text {th }} \text { Century? } \\
\text { How involved is academia with } \\
\text { financial patenting? }\end{array}$ & 445 Financial patents, $1971-2000$ & $\begin{array}{l}\text { The number of financial patent } \\
\text { applications and grants was modest, } \\
\text { but rapidly accelerated after a } 1998 \\
\text { judicial decision. } \\
\text { Patenting activity of investment banks } \\
\text { was related to their indirect ties to } \\
\text { academia; but the direct involvement } \\
\text { of academia and academics in } \\
\text { patenting is not related to their } \\
\text { finance-related research. }\end{array}$ \\
\hline \multicolumn{4}{|l|}{ B. Customers and Users: } \\
\hline Furst, Lang, and Nolle (2002) & $\begin{array}{l}\text { What are the characteristics of banks } \\
\text { that offer Internet services? }\end{array}$ & Survey, $3^{\text {rd }}$ quarter of 1999 & $\begin{array}{l}\text { Holding company affiliation, size, } \\
\text { urban location, fixed expenses, and } \\
\text { non-interest income are positively } \\
\text { related to offering Internet banking } \\
\text { services. }\end{array}$ \\
\hline Sullivan (2000) & $\begin{array}{l}\text { What are the characteristics of banks } \\
\text { in the } 10^{\text {th }} \text { Federal Reserve District } \\
\text { that offer Internet services? }\end{array}$ & Survey, $1^{\text {st }}$ quarter of 2000 & $\begin{array}{l}\text { Bank size, educated population, } \\
\text { population } 18-64 \text {, non-interest } \\
\text { expenses, and non-interest income are } \\
\text { positively related to offering Internet } \\
\text { banking services. }\end{array}$ \\
\hline $\begin{array}{l}\text { Frame, Srinivasan, and Woosley } \\
(2001)^{*}\end{array}$ & $\begin{array}{l}\text { What are the characteristics of large } \\
\text { banking organizations that adopted } \\
\text { small business credit scoring? }\end{array}$ & $\begin{array}{l}\text { Survey of } 200 \text { large banking } \\
\text { organizations, January } 1998 \text {; } \\
\text { bank call reports, June } 1997\end{array}$ & $\begin{array}{l}\text { The use of small business credit } \\
\text { scoring is negatively related to the } \\
\text { number of subsidiary banks, but } \\
\text { positively related to the number of } \\
\text { bank branches. }\end{array}$ \\
\hline
\end{tabular}


Appendix: A Summary of Empirical Studies of Financial Innovation (continued)

\begin{tabular}{|c|c|c|c|}
\hline Broad Category; Study & Relevant Research Questions & Data & Principal Conclusions \\
\hline Mantel (2000) & $\begin{array}{l}\text { Which consumers use electronic bill } \\
\text { payment services? }\end{array}$ & Survey of 1,300 consumers, 1999 & $\begin{array}{l}\text { Income, age, education, and gender } \\
\text { (women) are positive influences on } \\
\text { consumers' use of electronic bill } \\
\text { payment services. }\end{array}$ \\
\hline Mantel and McHugh (2001) & Which consumers use debit cards? & Survey of 1,300 consumers, 1999 & $\begin{array}{l}\text { Income, age, and local population are } \\
\text { positive influences on consumers' use } \\
\text { of debit cards }\end{array}$ \\
\hline \multicolumn{4}{|l|}{ C. Diffusion: } \\
\hline Hannan and McDowell (1984) & $\begin{array}{l}\text { Which banks were the early adopters } \\
\text { of automated teller machines? }\end{array}$ & $\begin{array}{l}\text { Survey of banks use of ATMs } \\
\text { between 1971-1979. }\end{array}$ & $\begin{array}{l}\text { Larger banks and those in more } \\
\text { concentrated markets adopt ATMs } \\
\text { earlier. }\end{array}$ \\
\hline Hannan and McDowell (1987) & $\begin{array}{l}\text { How does rivalry affect the process of } \\
\text { adopting ATMs? }\end{array}$ & $\begin{array}{l}\text { Survey of banks' use of ATMs } \\
\text { between 1971-1979. }\end{array}$ & $\begin{array}{l}\text { Earlier adoption of ATMs is related to } \\
\text { a rival's adoption and banks in less } \\
\text { concentrated markets react more } \\
\text { strongly to a rival's adoption. }\end{array}$ \\
\hline Saloner and Shepherd (1995) & $\begin{array}{l}\text { How does the user environment affect } \\
\text { early adoption of ATMs? }\end{array}$ & $\begin{array}{l}\text { Survey of banks' use of ATMs } \\
\text { between 1971-1979. }\end{array}$ & $\begin{array}{l}\text { Earlier adoption is related to the } \\
\text { presence of a larger number of users } \\
\text { and locations. }\end{array}$ \\
\hline Molyneux and Shamroukh (1996) & $\begin{array}{l}\text { What influenced the diffusion of } \\
\text { underwriting of junk bonds and of } \\
\text { note issuance facilities (NIFs)? }\end{array}$ & $\begin{array}{l}\text { Junk bond issues, 1977-1986; NIFs } \\
\text { arranged 1983-1986 }\end{array}$ & $\begin{array}{l}\text { Exogenous factors played a } \\
\text { significant role in explaining the } \\
\text { diffusion of junk bond underwriting; } \\
\text { bandwagon effects were important for } \\
\text { the diffusion of NIFs underwriting }\end{array}$ \\
\hline
\end{tabular}


Appendix: A Summary of Empirical Studies of Financial Innovation (continued)

\begin{tabular}{|l|l|l|l|}
\hline \multicolumn{1}{|c|}{ Broad Category; Study } & \multicolumn{1}{|c|}{ Relevant Research Questions } & \multicolumn{1}{c|}{ Data } & \multicolumn{1}{c|}{ Principal Conclusions } \\
\hline Akhavein, Frame, and White (2001) & $\begin{array}{l}\text { What were the characteristics of the } \\
\text { early adopters of small business credit } \\
\text { scoring? }\end{array}$ & $\begin{array}{l}\text { Survey of 200 large banking } \\
\text { organizations, 1998; } \\
\text { bank call reports; } \\
\text { information about the characteristics } \\
\text { of chief executives. }\end{array}$ & $\begin{array}{l}\text { Larger banking organizations and } \\
\text { those located in the New York Federal } \\
\text { Reserve district adopted small } \\
\text { business credit scoring earlier. Some } \\
\text { evidence that institution's with fewer } \\
\text { separate banks but more branches, } \\
\text { tended to adopt earlier. }\end{array}$ \\
\hline $\begin{array}{l}\text { D. Consequences and Social } \\
\text { Welfare: }\end{array}$ & $\begin{array}{l}\text { What were the effects of the telegraph } \\
\text { on cross-market price differentials of } \\
\text { securities? }\end{array}$ & $\begin{array}{l}\text { Securities price differentials before } \\
\text { and after the establishment of the } \\
\text { telegraph in the 1840s (U.S.) and } \\
\text { before after the trans-Atlantic } \\
\text { telegraph (1866) }\end{array}$ & $\begin{array}{l}\text { The introduction of the telegraph led } \\
\text { to a significant decrease in price } \\
\text { differentials. }\end{array}$ \\
\hline Garbade and Silber (1978) & $\begin{array}{l}\text { How do innovators of new securities } \\
\text { benefit: higher prices or larger } \\
\text { quantities? }\end{array}$ & $\begin{array}{l}\text { Sample of 58 securities that } \\
\text { experienced 1,944 publicly traded } \\
\text { issues over the 1974-1986 period. }\end{array}$ & $\begin{array}{l}\text { Innovators do not charge monopoly } \\
\text { prices, but do achieve higher market } \\
\text { shares than rivals. }\end{array}$ \\
\hline Tufano (1989) & $\begin{array}{l}\text { What was the stock market reaction to } \\
\text { issuing original issue deep discount } \\
\text { bonds (OIDs)? }\end{array}$ & $\begin{array}{l}\text { Sample of OID issues between 1981 } \\
\text { and 1987. }\end{array}$ & $\begin{array}{l}\text { Issues during 1981 and 1982, which } \\
\text { had certain tax benefits, were } \\
\text { associated with positive stock-price } \\
\text { responses. No significant response } \\
\text { for OIDs following the tax law } \\
\text { change. }\end{array}$ \\
\hline Varma and Chambers (1990) & $\begin{array}{l}\text { Is the use of Treasury STRIPS driven } \\
\text { by the need for market completeness } \\
\text { or speculative purposes? }\end{array}$ & $\begin{array}{l}\text { Sample of 58 notes and bonds trading } \\
\text { between July 1990 and December } \\
\text { 1994. }\end{array}$ & $\begin{array}{l}\text { STRIPS program is primarily for } \\
\text { making markets more complete. }\end{array}$ \\
\hline Grinblatt and Longstaff (2000)
\end{tabular}


Appendix: A Summary of Empirical Studies of Financial Innovation (continued)

\begin{tabular}{|c|c|c|c|}
\hline Broad Category; Study & Relevant Research Questions & Data & Principal Conclusions \\
\hline $\begin{array}{l}\text { Frame, Srinivasan, and Woosley } \\
(2001)^{*}\end{array}$ & $\begin{array}{l}\text { Does SBCS affect small business } \\
\text { credit availability? }\end{array}$ & $\begin{array}{l}\text { January } 1998 \text { survey of } 200 \text { large } \\
\text { banking organizations. Also, used } \\
\text { bank call report information. }\end{array}$ & $\begin{array}{l}\text { SBCS is associated with significantly } \\
\text { more lending. }\end{array}$ \\
\hline Frame, Padhi, and Woosley (2001) & $\begin{array}{l}\text { Does SBCS affect small business } \\
\text { credit availability in low- and } \\
\text { moderate-income areas? }\end{array}$ & $\begin{array}{l}\text { January } 1998 \text { survey of } 200 \text { large } \\
\text { banking organizations. Also used } \\
\text { census tract-level data on small } \\
\text { business lending and population } \\
\text { characteristics for the southeastern } \\
\text { U.S. in } 1997 \text {. }\end{array}$ & $\begin{array}{l}\text { SBCS is associated with significantly } \\
\text { more lending. This is especially true } \\
\text { for low- and moderate-income areas. }\end{array}$ \\
\hline Berger, Frame, and Miller (2002) & $\begin{array}{l}\text { Does SBCS affect small business } \\
\text { credit availability, loan pricing, and } \\
\text { loan risk? }\end{array}$ & $\begin{array}{l}\text { January } 1998 \text { survey of } 200 \text { large } \\
\text { banking organizations. Also used the } \\
\text { Survey of Terms of Bank Lending for } \\
\text { loan-level information on loan terms } \\
\text { and perceived risk. }\end{array}$ & $\begin{array}{l}\text { SBCS is associated with significantly } \\
\text { more lending, higher average loan } \\
\text { prices, and riskier loans. }\end{array}$ \\
\hline Bhargava and Fraser (1998) & $\begin{array}{l}\text { Did the formation of Sec. } 20 \text { subs } \\
\text { benefit bank holding companies } \\
\text { (BHCs)? }\end{array}$ & $\begin{array}{l}\text { Event studies for large BHCs, 1987- } \\
1996\end{array}$ & $\begin{array}{l}\text { Only early permission announcements } \\
\text { were associated with positive } \\
\text { abnormal stock returns. }\end{array}$ \\
\hline Fields and Fraser (1999) & $\begin{array}{l}\text { What is the pay-performance of the } \\
\text { CEOs of BHCs that form Sec. } 20 \\
\text { subs? }\end{array}$ & Large BHCs 1992 & $\begin{array}{l}\text { The sensitivity is higher relative to } \\
\text { other BHCs, but less than that for } \\
\text { investment banks. }\end{array}$ \\
\hline
\end{tabular}


Appendix: A Summary of Empirical Studies of Financial Innovation (continued)

\begin{tabular}{|l|l|l|l|}
\hline \multicolumn{1}{|c|}{ Broad Category; Study } & \multicolumn{1}{|c|}{ Relevant Research Questions } & \multicolumn{1}{c|}{ Data } & \multicolumn{1}{c|}{ Principal Conclusions } \\
\hline Gande, Puri, and Saunders (1999) & $\begin{array}{l}\text { What are the competitive effects of } \\
\text { BHC entry into securities } \\
\text { underwriting? }\end{array}$ & Debt issues sample, 1985-1996 & $\begin{array}{l}\text { BHC entry has led to decreased } \\
\text { market concentration, narrower } \\
\text { underwriter spreads, and decreased ex } \\
\text { ante yields. }\end{array}$ \\
\hline Cornett, Ors, and Tehranian (2002) & $\begin{array}{l}\text { What are the financial consequences } \\
\text { for BHCs that establish Sec. 20 subs? }\end{array}$ & Large BHCs, 1987-1997 & $\begin{array}{l}\text { These BHCs have increased } \\
\text { revenues,but their risk profiles are } \\
\text { unchanged. }\end{array}$ \\
\hline DeYoung (2001a) & $\begin{array}{l}\text { How do de novo Internet-only banks } \\
\text { different from conventional de novo } \\
\text { banks? }\end{array}$ & Late 1990s bank data & $\begin{array}{l}\text { De novo Internet-only banks are less } \\
\text { profitable, have lower business } \\
\text { volumes, and higher labor } \\
\text { expenditures than other de novo } \\
\text { banks. }\end{array}$ \\
\hline DeYoung (2001b) & $\begin{array}{l}\text { Do start-up Internet-only de novos } \\
\text { improve their financial performance } \\
\text { more rapidly than do conventional de } \\
\text { novos? }\end{array}$ & Late 1990s bank data & $\begin{array}{l}\text { De novo Internet-only banks improve } \\
\text { their financial performance more } \\
\text { rapidly than do conventional de } \\
\text { novos. }\end{array}$ \\
\hline
\end{tabular}

* Study appears in two sections 